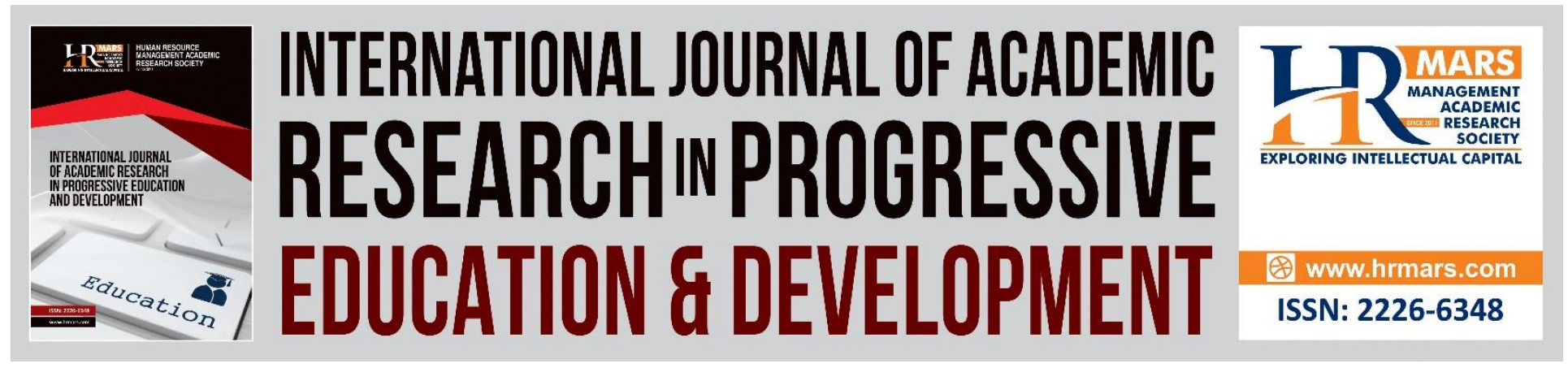

\title{
Cooperative Behaviour in Peer Interactions During Child's Initiated Activities
}

Nordin Mamat, Abdul Rahim Razalli, Abdul Talib Mohamed Hashim, Abdul Rahim Hamdan, Mohd Mahzan Awang

To Link this Article: http://dx.doi.org/10.6007/IJARPED/v10-i2/9094 DOI:10.6007/IJARPED/v10-i2/9094

Received: 01 March 2021, Revised: 26 March 2021, Accepted: 16 April 2021

Published Online: 05 May 2021

In-Text Citation: (Mamat et al., 2021)

To Cite this Article: Mamat, N., Razalli, A. R., Hashim, A. T. M., Hamdan, A. R., \& Awang, M. M. (2021). Cooperative Behaviour in Peer Interactions During Child's Initiated Activities. International Journal of Academic Research in Progressive Education and Development, 10(2), 402-409.

Copyright: (C) 2021 The Author(s)

Published by Human Resource Management Academic Research Society (www.hrmars.com)

This article is published under the Creative Commons Attribution (CC BY 4.0) license. Anyone may reproduce, distribute, translate and create derivative works of this article (for both commercial and non-commercial purposes), subject to full attribution to the original publication and authors. The full terms of this license may be seen at: http://creativecommons.org/licences/by/4.0/legalcode

Vol. 10(2) 2021, Pg. 402 - 409

http://hrmars.com/index.php/pages/detail/IJARPED

JOURNAL HOMEPAGE

Full Terms \& Conditions of access and use can be found at http://hrmars.com/index.php/pages/detail/publication-ethics 


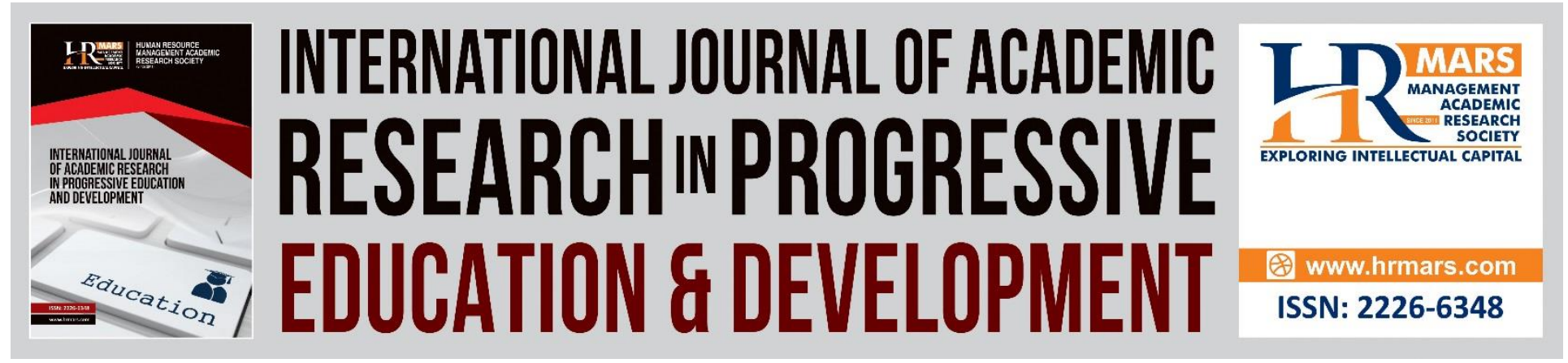

\title{
Cooperative Behaviour in Peer Interactions During Child's Initiated Activities
}

\author{
Nordin Mamat, Abdul Rahim Razalli, Abdul Talib Mohamed \\ Hashim, Abdul Rahim Hamdan \\ Universiti Pendidikan Sultan Idris \\ Email: nordin@fppm.edu.my \\ Mohd Mahzan Awang \\ Universiti Kebangsaan Malaysia
}

\begin{abstract}
This study aims to identify the cooperative behaviour in peer interaction during child's initiated activities. The objective to focus on interaction between children during learning activity and free play time at early childhood education centres. This study uses qualitative data. A total of 25 children in pre-school in Selangor, Malaysia were observed their interaction during learning activities and free play. The findings show two pattern of interaction: first, children engage in cooperative activity caused by shared intentionality. they cooperated with each other to do the group task. This activity gave the children a chance to practice cooperative behavior. Second, friends were instigated peer interaction. The most interesting findings emerging from the observation, peer interaction in such involved a popular child who would always lead and coordinate games. In conclusion, cooperative behaviour during children's initiated activities play important roles in learning activities and assist the development of children, especially in terms of social skills.
\end{abstract}

Keywords: Pre-school, Cooperative, Interaction, Early Childhood

\section{Introduction and background}

Cooperation refers to teamwork, collaboration, combining effort, give-and-take, or working together or joint operation or action between two or more children. Cooperative behaviour is one of the most popular behaviour occurring during peer interaction in pre-school. This type of interactions used by pre-school teachers in learning activities are channels for establishing a harmonious relationship among children. According to Lazlo, (2013), collaborative learning is a way that is based on the capitalization of collaboration within a group; a teaching tool for group work, communication and collaboration; used when there is a real interdependence among 
group members in a task, a sense of responsibility to the group and its goals; and based on discussions between the participants and the active work through teaching material.

In early childhood setting, teacher should prepare the setting of environment that encourage interaction between children. The center always reviews program routine for possible influence cooperative behavior among children. Plan the program to meet child cooperative in activities and evaluate the plan as required. Clearly identify strategies to achieve acceptable alternative behaviours in the plan. Cooperative behaviours in early childhood setting shown difficulties as children do not have advanced cooperation skills (Bartolome, et al., 2020). According to Zisopoulou (2019) teachers face challenges when applying collaborative learning even though collaborative learning is frequently used in early childhood settings. In addition, teachers have highly evaluated the results of the method, which includes social and cognitive skills and the effects of collaborative learning evaluation and skills advancement. Children need to interact and be tolerant, understanding, supportive and respectful in learning activities. Children who can feel a friend's concern and respect for them will have a sense of being valued, accepted, and feel that they are taken care of and loved (Luen et al., 2015).

\section{Aim and Objective of Study}

The aim of this research is to identify the cooperative behaviour in peer interaction during children's initiated activities.

- The objective to focus on interaction between children during learning activity and free play time at early childhood education centres.

\section{Literature Review}

According to Warneken, Chen and Tomasello (2006), cooperative interaction demonstrates some form of shared intentionality. In this case, children do not just react to one another's actions, but they have intentions toward the other's intentions; they must understand the intentions of the other and incorporate them into their own intention. Most of the pre-school activities provide an environment for sharing and stimulate cooperative behaviour among children. This activity gave the children a chance to practise cooperative behaviour as one of the pre-school norms which they were supposed to practise. This cooperative behaviours were instigated the children to finish their individual and group tasks (Luen et al., 2015). Cooperation in outdoor activities and free play occurred when they played together. The types of cooperation have been divided into two; firstly, the activities which were planned by the teacher, such as physical education and secondly cooperation happened in activities which were planned by the children. These activities were independent where the children were not restricted to their friend's group in class, and instead, they could choose their close friends to work together as a team. This cooperation would be related to past relationships, for example they would play together. Secondly, cooperation happened in activities which were planned by themselves, usually during free time in the morning or after school time, inside the pre-school, for example at the playground. This cooperation involved the close friends with whom they usually played.

According to Hermes (2016) cooperation is essential for human society, and children engage in cooperation from early on. They select their partners for cooperation, choose selectively whom 
to learn from (e.g. preferring reliable over unreliable models) on a rational basis. Children's selective model choice thus reveals an early rational competence: They infer characteristics from past behaviour and flexibly consider what characteristics are relevant for certain tasks. Meanwhile, findings from Oneren Sendil and Erden (2019) study suggested that providing selfdirected activity to children with some teacher intervention for preventing problematic peer interactions gives contexts for positive peer interactions. Children engage in cooperative activity. In this study, this self-directed activity towards is frequently same goal or same intentions. Children actively joined an activity set up by their group partner and friends. They did tasks parallel with what their partners were doing. They acted according to what their partners were doing. The children were able to cooperate with their partners in a variety of tasks between two and more children. They needed to work cooperatively and find the answer to achieve that joint goal. A full commitment is important when having one goal and every child should be given support for achieving the target.

Fauzah and Suryani (2013) found that interaction in learning activities is a key process for a teacher to deliver skills and knowledge to children. Interaction among children in learning activities starts with the preparation of lesson plans, teaching materials, strategy and process. Through interaction, a teacher can implement activity planning based on the learning outcomes. Most teacher conversations are in the form of lecturing in learning activities. Interactions play an important role in learning activities to engage in learning processes and enhance children's experience, skills and knowledge (Norsita \& Zainal, 2014). Research has also stressed the fact that adult centred approaches may limit children's social exploration toward establishing social interactions with peers and create dependence on the teacher. Meanwhile, Mamat et al. (2018) findings emphasise the directive in teacher-initiated and relationships in child-initiated activities approaches. Teachers engaged in child centred scaffolding behaviours, which included fewer directive forms of guidance and emphasized naturally occurring peer exchanges, adult centred scaffoldings were used to prevent or interrupt conflict interactions. Based on review showed that collaborative learning methods provide a solution this new challenge inclusive research demonstrating that collaborative methods and techniques can enhance positive attitudes towards learning, school performance and self-esteem of preschoolers, promoting positive interaction and mutual support between children.

\section{Methodology}

A total of 25 pre-school children in Selangor, Malaysia were selected to complete a checklist related to interactions between children during learning activities and free play. This research instrument is partly derived from the research Development of a Comprehensive and Integrated Model of Quality Malaysian Early Childhood Care and Education-Project 3/TLA: Determining Contributing Factors of Quality ECCE (Ahmad, et al., 2021). The instrument was divided into two sections. Section A included interaction during teaching activity and Section B included interaction during free play and initiated by children. Direct observation of children's free play and in-depth interviews were conducted with the children within 16 weeks. Observation based on instruments from the ECCE Research Project which included two main standards, an element of children's learning and meaningful learning. The qualitative part of the research employed a 
combination of observation and interviews to serve as data collection instruments as well as means of data triangulation; to estimate the validity and reliability of data and research procedures (Mamat, et al, 2017). Observations analysis were done by at least two researchers for two consecutive days at each selected child centres. The interviews were divided into individual interviews based on photos of child.

\section{Findings}

\section{Cooperative behaviour activity with Shared Intentionality}

In teacher's initiated activity, children could work together to finish their individual and group tasks. A cooperative behaviour is initiated from a group activity which can be identified in the case below.

Ellin, Adam and Canny sat together to solve a group task which was given to them...they discussed together. Adam led this task...after that they helped each other count and answer the questions. (Observation Session 1: Child 7, Child 1 and Child 6)

The children cooperated with each other to do the group task. This activity gave the children a chance to practice cooperative behaviour as one of the pre-school norms which they were supposed to practice. This cooperative behaviour was instigated the children could finish their group tasks. Features from this problem-solving task had shown that the cooperative behaviour and determine how they coordinate their actions in cooperative activities. The observation showed Ardini, Arif and Jenny working together to find answers. They referred to a book to compare and match the exercise. They worked together to solve the problem of "match" (Observation P001: Child 5, and child 4 and Child 11). In these interactions. children had an intention (e.g., they had the goal to get the "match" answer). In this case the activity towards shared intentions occurred frequently. The children actively joined an activity set up by their group partner and friends. They did tasks parallel with what their partners were doing. They acted according to what their partners were doing. They needed to work cooperatively and find the answer to achieve that goal.

Based on my observation with child's initiated activity, as regards to the cooperation during the free time, normally the children would choose their regular friends compared to the activities which the teacher had planned. There were three girls playing see-saw during free time. Two girls sat at the opposite ends of the see-saw with the Chinese girl [May Yee] and the Malay girls [Sya] trying to balance on either sides. Molly pushed May Yee's seat to ensure enough weight for them [May Yee and Sya] (Observation P113: Child 14, Child 19 and Child 22). After that interviewed them:

R:What were you trying to do? Sya: May we play see-saw? Molly: play together...work together. R:Why did you push Molly's seat May Yee? May Yee: Play together[cooperate together] R: Do you like to play with Irda, Min Yin? Why? May Yee: em..em (nodded) [yes]...Play together.

This cooperation behaviour occurred in activities which were planned by themselves, usually during free time in the morning or after school time, for example at the playground. This cooperation involved the close friends with whom they usually played. Next case, two children 
Vol. 10, No. 2, 2021, E-ISSN: 2226-6348 @ 2021 HRMARS

held each other's hands and raised their hands up and other children would walk under it (tunnel space) (Observation Session: Outdoor activity).

\section{Friends were Instigated Cooperative Behaviour}

The most interesting findings emerging from the cooperative behaviour involved a popular child who would always lead and coordinate games. From the observation of interactions between three children (Canny, Harun, Asah and Jenny) always led in the pre-school activities such as singing the Malaysian national anthem and reciting the dua (prayer). Children like Canny, Asah, Vejay and Wee Jo who were fluent in Malay frequently offered their assistance to their group in school activities. This case was described as the teacher put on some educational music on the computer. Some music has a lot of beat or rhythm that makes you want to dance. Vejay and Harun got up and start dancing together. Then a few children followed them including Suriani. Suriani danced with Vejay. Vejay told her that he could do a tap dance, then he showed her the moves, Suriani imitated the moves, and they danced happily with the others. When the teacher switched off the music, they settled down and laughed, satisfied with their dancing (Observation Session 2, Child 21, Child 6, Child 9 and Child 23).

In this study, a popular child instigated others to join the activity. This next case demonstrates the amount of time spent in cooperative behaviour by a child. It showed a child teaching another child how to play a new game. Wee Jo taught a girl to play 'teng-teng' [hopscotch]. This process occurred several times. The first time he showed Sree how to play it, and then let her have a try. Wee Jo was not satisfied with Sree's performances, and so he showed it to her once again. Timeconsuming cooperation in terms of the amount of time spent by Wee Jo with Sree is important here. Here would emphasise the spontaneous help and play activity coordinated between Wee Jo and his friends.

\section{Discussion}

Based on typical scenes of peer interaction, cooperative behaviours occurring frequently during learning activities, either in the classroom or during outdoor activities like physical education, or free play within the school's geographical space. The children show a willingness to help, share and cooperate with other children. However, cooperative behaviour in outdoor activities happened when children played together. That the ability to cooperate with others develops further in the pre-school years is consistent with the findings of Mamat et al.,(2017); Eisenberg, Fabes \& Spinrad (2006) regarding helpful and sharing towards others. Similarly with Warneken, Chen \& Tomasello (2006), cooperative interaction demonstrates some form of shared intentionality. However, pre-schoolers may need additional support from the teacher in order to create positive social contacts with their peers as suggested by Fauzah and Suryani (2013) and Norsita and Zainal (2014) that interaction between teacher and children play an important role in learning activities to engage in learning processes and enhance children's experience, skills and knowledge.

The cooperative behaviour occurring frequently during learning activities, but the most interesting findings emerging from the cooperative behaviour involved a popular child who would always lead and coordinate games. Their friends were instigated peer interaction in such involved a popular child who would always lead and coordinate games. In this study, a popular 
child instigated others to join the activity. With confident she or he demonstrated and showed other child how to play a new game. This process occurred several times. From the first time he or she showed how to play it with the spontaneous help and play the activity. It is in line with Sendi \& Erden (2019) suggested that providing self-directed activity to children gives contexts for positive peer interactions. Children instigated their friend to join an activity set up by their group partner and friends. A full commitment is important when having one goal and every child should be given support for achieving the target.

\section{Conclusion}

In conclusion, based on the findings showed that two pattern of interaction: first, children engage in cooperative activity caused by shared intentionality. they cooperated with each other to do the group task. Second, friends were instigated peer interaction. The most interesting findings emerging from the observation, peer interaction in such involved a popular child who would always lead and coordinate games. The impact of this research to theory gives a new input to teachers that pattern of interaction among children basically engage in cooperative activity cause of shared intentionality and friends instigated peer interaction. Therefore, cooperative behaviour during children's initiated activities play important roles in learning activities and assist the development of children, especially in terms of social skills.

\section{Acknowledgement}

This part of the research "Development of a comprehensive and integrated model of quality Malaysian early childhood care and education-project 3/TLAA: determining contributing factors of quality ecce" (2015-0024-106-04-3) is funded by the Ministry of Finance through the Malaysian Ministry of Education. Special appreciation is also dedicated to the National Child Development Research Centre, Universiti Pendidikan Sultan Idris, Malaysia for giving us the opportunity to carry out this research project.

\section{Corresponding Author}

Associate Prof. Dr. Nordin Mamat

Associate Professor Department of Early Childhood Education Faculty of Human Development Universiti Pendidikan Sultan Idris Perak Malaysia

Email: nordin@fpm.upsi.edu.my

\section{References}

Ahmad, H., Mamat, M., Mustafa, M. C., Yusoff, S. I. M. S. I. M. (2021). Validating the teaching, learning, and assessment quality of Malaysian ECCE instrument. International Journal of Evaluation and Research in Education (IJERE), 10(1) pp. 135 141 ISSN: 2252-8822, DOI: 10.11591/ijere.v10i1.20857.

Bartolome, M. T., Mamat, N., \& Masnan, A. H. (2020). Exploring Kindergarten Teachers' Perspectives in Parental Involvement In The Philippines. Southeast Asia Early Childhood Journal, Vol. 9 (1), 2020 (44-58) ISSN 2289-3156 /elSSN 2550-1763. 
INTERNATIONAL JOURNAL OF ACADEMIC RESEARCH IN PROGRESSIVE EDUCATION AND

DEVELOPMENT

Vol. 10, No. 2, 2021, E-ISSN: 2226-6348 @ 2021 HRMARS

Eisenberg, N., Fabes, R. A., \& Spinrad, T. L. (2006). Prosocial development. In N. Eisenberg (Ed.), Handbook of child psychology: Social, emotional, and personality development (Vol. 3, pp. 646-718). New Jersey: Wiley.

Hermes, J., Behne, T., Studte, K., Zeyen, A., Gräfenhain, M., \& Rakoczy, H. (2016). Selective cooperation in early childhood - how to choose models and partners. PLoS One, 11(8) doi:http://dx.doi.org.ezpustaka2.upsi.edu.my/10.1371/journal.pone.0160881

Luen, C. L., Ayob, A., \& Mamat, N. (2015). Aktiviti boneka jari membentuk interaksi sosial kanakkanak. Jurnal Pendidikan Awal Kanak-Kanak Kebangsaan. 4 (1), 29-49.

Lazlo, I. (2013). Cooperative learning in the kindergarten. Euromentor Journal, 4(3), 98-104.

Norsita, A., \& Zainal, M. (2014). Tinjauan awal interaksi guru-kanak-kanak dalam pemupukan pemikiran kreatif kanak-kanak prasekolah. In Proceeding of the Social Sciences Research. (Pp. 735-746). Sabah: Worldconferences. Net.

Mamat, N., Radzi, N. M. M., Luen, L. C., \& Yassin, S. M. (2017). The Selection of Meaningful Approach to Assess Children's Science Process Skills. International Journal of Academic Research in Business and Social Sciences. 7(4), 860-869. DOI:10.6007/IJARBSS/v7-i4/2897

Mamat, N., Luen, L. C., Radzi, N. M. M., Yassin, S. M., \& Yusoff, S. I. M. (2018). Reliability, Validity and Fairness of Interviews for Teaching and Learning Project in Quality Early Childhood Care and Education: Preliminary Study. International Journal of Academic Research in Business and Social Sciences. 8(6), 1283-1292. http://dx.doi.org/10.6007/IJARBSS/v8i6/4516

Mamat, N., Luen, L. C., Mustapha, M. C., Razalli, A. R., \& Hashim, A. T. M. (2019). The Quality of PERPADUAN Pre-school Environment and Human Resources: Teachers' Satisfaction on their Career Development. International Journal of Academic Research in Business and Social Sciences. 9(5), 882-897. http://dx.doi.org/10.6007/IJARBSS/v9-i5/6015

O'kane, J. C., \& Goldbart, J. (2016). Communication before speech: Development and assessment. London: David Fulton Publishers.

Sendi, O. C., \& Erden, F. T. (2019). Understanding the Gaps Between Turkish Teachers' Beliefs and Practices for Dealing with Preschoolers' Peer Relationship Problems, Early Education and Development. 30(5), 608-638.

Fauziah, S. N. A. R., \& Suryani N. A. R. (2013). Children interaction patterns exhibited during learning activities: A case study at a selected public kindergarten in Malaysia. In Prosiding International Conference on Social Science Research. (Pp.1389-1412). Penang: Worldconferences. Net.

Warneken, F., Chen, F., \& Tomasello, M. (2006). Cooperative Activities In Young Children And Chimpanzees. Child Development, 77(3), 640-663.

Zisopoulou, E. (2019). Collaborative learning in kindergarten: challenge or reality? erken çocukluk çalişmalari dergisi, 3(2), 335-351.

doi:http://dx.doi.org.ezpustaka2.upsi.edu.my/10.24130/eccd-jecs.1967201932113 